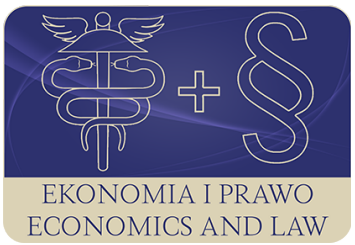

EKONOMIA I PRAWO. ECONOMICS AND LAW

Volume 16, Issue 1, March 2017

p-ISSN 1898-2255, e-ISSN 2392-1625

www.economicsandlaw.pl

ORIGINAL ARTICLE

received 01.08.2015; revised 18.10.2016; accepted 31.03.2017

Citation: Malinowski, D. (2017). Barriers to expansive fiscal policy against the background of the macroeconomic situation of the euro area. Ekonomia i Prawo. Ecomomics and Law, 16(1): 87-105. doi:10.12775/EiP.2017.006.

\title{
Barriers to expansive fiscal policy against the background of the macroeconomic situation of the euro area
}

\author{
DARIUSZ MALINOWSKI \\ Warsaw School of Economics, Collegium of Socio-Economics, Chair of the Theory of Economic \\ Systems, ul. Wiśniowa 41, 02-520 Warszawa, Poland \\ వdmalino@sgh.waw.pl
}

\begin{abstract}
Aim: In the article, the Author analyses the possibilities of instituting an expansive fiscal policy in individual euro zone countries. In addition, barriers to effective transmission of fiscal expansion to the level of real output in the euro zone economy will be identified against the background of economic theory.

Results: The Author also show how the implementation of different strategies of monetary policy and exchange rate policy affect the effectiveness of the growth of the budget deficit in its impact on the economic growth rate.
\end{abstract}

Keywords: budget deficit; public debt; expansive fiscal policy

JEL: E6; H6

\section{Introduction}

Over the past few years the euro zone has been witnessing a very low economic growth rate (with the real volume of actual output even shrinking in some years). Economists seem to be in agreement that the euro zone needs the application of the supply-side concept of economic growth as only this approach would make it possible for euro zone economy to enter the path of long-term real GDP growth. In this concept, the economic recovery process is initiated with an in- 
crease in corporate investment and growth of real output rather than growth of the volume of global demand (private consumption and public consumption). Improvement of the conditions for investment and production through economic policy is the principal instrument of this concept. In the euro zone economy this would involve, among others, reduction of the tax burden, reduction of labour costs, improvement of labour market flexibility, reduction of budgetary expenditure in relation to GDP, reform of the public pension scheme, reform of the public health care system. Thanks to the improved environment for investments and production (improvement of economic efficiency), new investment projects will be launched and primary real output growth will follow. This will in turn increase revenues of production factors and automatically the volume of global demand which will trigger secondary production growth. Improvement of conditions for investment and production is a source of long-term economic growth as it increases the production possibilities of the economy (by moving the boundary of the full utilization of the resources of factors of production). Acting on the economy on the supply side means also that economic growth is not built (as it is in the case of acting on the demand side) on the foundation of bad macroeconomic events (such as inflation, budget deficit growth, depreciation of the national currency) which become barriers to its growth in the long-run. What is also worth emphasizing is the fact that improvement of conditions for investment and production increases the readiness of enterprises to respond to the growth of global demand - resulting also from fiscal expansion - with growth of real output (it can also have a positive influence on the scale of the demand effect of this expansion).

The positive effects of the initiation of the supply-side concept of economic growth on real output can be seen as a rule only after a few years. The aim of fiscal expansion is in turn to increase the economic growth rate in the short-run. It can be argued that its application contributes to recovery and thus creates a better social climate at the time when deep structural changes (being the essence of the supply-side concept) are launched and their effects are waited for.

In the present article, the Author analyses the possibilities of instituting an expansive fiscal policy in individual euro zone countries. In addition, barriers to effective transmission of fiscal expansion to the level of real output in the euro zone economy will be identified against the background of economic theory. The Author will also show how the implementation of different strategies of monetary policy and exchange rate policy affect the effectiveness of the growth of the budget deficit in its impact on the economic growth rate.

\section{The methodology of research}

As it will be shown further on, the level of public debt and state budget deficit are factors conditioning a possible application of an expansive budget policy. In economics, public debt is defined as a sum of all state obligations at a given moment. Public debt calculated at the end of the $t$ year shows the total liabilities 
of the state at the end of the $t$ year. The state budget result for the $t$ year in economic terms (i.e. the result which according to economic theory best reflects the condition of public finances of the state in a given year) is the result which shows how the total liabilities of the state changed in the $t$ year. If the budget in a given country in the $t$ year closed with a high economic deficit in relation to GDP, it does not automatically mean that the condition of public finances should be assessed in a negative way. Why so? What we may have to do with is low public debt as a percentage of GDP which means that there is room there for high budget deficits for some time and thus room for acting on the economic growth rate with fiscal expansion (Wernik, 2011, p. 13).

In this article, the current situation of public finances of the euro zone countries will be presented with the help of data calculated in accordance with ESA 2010 methodology. The methodology was developed by Eurostat and approved by the European Commission. All member states of the European Union are obliged to present the condition of public finances according to the ESA 2010 methodology (for the needs of Eurostat). The methodology referred to applies not only to public finances but specifies also the way of calculating other macroeconomic categories. The year 2014 was the first for which EU countries had to calculate the level of public debt and budget deficit according to the ESA 2010 methodology. The methodology replaced the hitherto applied ESA 95. As regards public finances, the difference between the two methodologies is relatively small. The change is that an item which simultaneously contributes to increasing state liabilities cannot be treated as state budget revenue. Thus, an item of this kind will not be able to improve the state budget result nor reduce the level of public debt.

In financial reporting ESA 2010 Methodology adopts the accrual-basis instead of the cash-basis, i.e. the value of liabilities is calculated for the moment of their emergence and not for the moment of the inflow or outflow of cash. Moreover, debt is given at market not nominal values (Eurostat, 2010).

The subject scope of public debt results from the definition of the public sector finances. According to the ESA 2010 methodology, the sector of public finances comprises all institutional entities which operate on non-market principles and the effects of their activity are intended for private and mass consumption, and which are primarily financed from mandatory contributions transferred by other sector entities and (or) all institutional entities the basic task of which is the redistribution of the national income.

According to ESA 2010, the institutional entities of the sector of public finances include:

- units of public authorities (with the exception of state-owned companies and other legal entities belonging to the sector of enterprises or the sector of financial institutions) which administer and finance the group of activity aimed mainly at supplying non-market goods and services intended to satisfy social needs; 
- non-commercial institutions, treated as legal persons which operate on non-commercial principles and are controlled and financed mainly by public authorities;

- autonomic pension funds.

According to ESA 2010, the sector of public finances consists of the following sub-sectors:

a. Subsector of central public finances - all administrative units and other central institutions the competences of which cover in principle the whole economic territory subordinated to a given authority with the exception of the management of social security funds. This sector includes the non-commercial institutions which are controlled and financed primarily by central-level public authorities and whose competences cover the same territory.

b. Subsector of local public finances - types of public institutions the competences of which cover the local economic area only, with the exception of local social security funds. This subsector includes the non-commercial institutions which are controlled and financed primarily by local public authorities and the competences of which are limited to the area of action of local authorities.

c. Subsector of federated public authorities - separate institutional entities performing the function of public authorities which are a level lower than central authorities and a level higher than the institutional units of local authorities, with the exception of the management of social security funds. This subsector includes non-commercial institutions which are controlled and financed primarily by the public authorities of federated states and the competences of which cover the economic area of these states.

d. Subsector of social security funds - all central and local institutional units the core activity of which consists in the provision of social services and which satisfy the following criteria:

- particular groups of the population have a mandatory duty to participate in the programme or pay contributions to it;

- public authorities are responsible for the management of the institution in terms of setting and approving the rates of insurance contributions and benefits, irrespective of their role as an organ of supervision or as an employer.

The ESA 2010 methodology makes it clear that public debt refers solely to the indebtedness of the entities of the sector of public finances and not to the indebtedness of the public sector as a whole. Apart from the sector of public finances, the public sector includes also public enterprises and public banks which are self-financing units. They finance their operations from commercial activity and not from public funds and even increase the latter by payment to the budget of taxes, part of profit or dividend.

Under the ESA 2010 methodology the object scope of public debt was specified by listing the types of liabilities. The volume of public debt equals the total of all public finance sector liabilities in the following categories: cash and de- 
posits held, securities other than shares, derivates included, loans and other accounts due (trade credits, liabilities in virtue of overpaid taxes, non-exercised social insurance benefits and remunerations, unpaid lease, outstanding dues in virtue of interest on debt) as well as small-scale stocks and shares as well as other technical and insurance reserves which emerge in some cases.

It should be emphasized that owing to such a specification of the object scope and subject scope of public debt, the state budget result and public debt calculated according to the ESA 2010 methodology are almost identical with the level of these categories calculated in economic terms. This causes that data calculated according to ESA 2010 reflect the actual condition of the state of public finances of a given state.

\section{The research process and the results of research}

\subsection{Economic growth rate of euro zone countries in years 2010-2014}

In 2009, the great banking crisis of 2008 began to affect the performance and results of real economy and the euro zone experienced a period of deep economic recession - the real GDP declined by 4.5\%. In the years 2010-2011 slight economic recovery followed (with the economic growth rate reaching $1.9 \%$ and $1.6 \%$, respectively). Yet, in subsequent years the euro zone plunged into economic stagnation, i.e. the economic growth rate oscillated around $0 \%$. In 2012, the real GDP decreased by $0.8 \%$ and in 2013 by $0.4 \%$ to increase by 0.8 \% in 2014 (Eurostat, 2015). The European Commission forecasts that in 2015 the real GDP will increase by 1.3\%. In the years 2010-2014, and thus in the period following the year of deep recession, the average annual economic growth rate of the euro zone amounted to $0.64 \%$. Table 1 shows data for real output growth rate in all countries of the euro zone in the years 2010-2014.

In the 12 euro zone countries, the average annual rate of the change of real output in the years 2010-2014 was below 1.5\%. Further in the analysis, this group of countries will be referred to as the group with the lowest economic growth rate. As many as five countries of the group registered in the analysed period a negative average annual rate of the real GDP change. They were: Greece, Cyprus, Portugal, Italy and Spain. In four other countries the average annual economic growth rate ranged from $0 \%$ to $1.0 \%$ (France, the Netherlands, Finland, Slovenia). In three countries (Belgium, Ireland, Austria), it barely exceeded $1.0 \%$. These twelve countries are thus the main candidates for the application of an expansive fiscal policy with the aim of short-term recovery in economic growth. An increase of the real production growth rate would in turn create a better social climate for deep structural reforms (that is changes which would improve economic efficiency in an essential way) which have al- 
ready been mentioned as prerequisites for entering a period of a long-term, adequately high, economic growth rate.

What is worthwhile emphasizing in this place is that after the deep recession which affected the majority of countries worldwide in 2009, many of the largest non-European economies have been recently developing at a much faster rate than the euro zone economy. This is also true of the USA economy, the average annual real GDP growth of which in the years 2010-2013 reached 2.2\%. In the first two quarters of 2014, the American economy was developing at a rate higher than 4.5\% (Bureau of Economic Analysis, 2015). The US Department of Trade estimates that in 2014 the real GDP increased by 2.4\%. According to IMP forecasts the economic growth rate in the USA in the years 2015-2016 is to reach $3.6 \%$ and $3.3 \%$, respectively. Table 2 shows the mean economic growth rate in the years 2009-2013 for selected non-European countries, the economies of which belong to the largest world economies (according to GDP at market prices in the purchasing power parity). What is worth pointing out is that over the past few years, the only country to record a similar low economic growth rate as the euro zone was Japan.

\subsection{Mechanism of the impact of an expansive fiscal policy on the volume of real output}

An expansive budget policy affects the volume of real output by increasing the volume of global demand. The effectiveness of this policy in increasing the real volume of global demand is the highest when the fiscal expansion takes the form of the growth of state expenditures on the purchase of products which is fully financed with the growth of the budget deficit (and thus through drawing public debt) (Domańska, 1992, p. 42). With the smaller, primary ${ }^{1}$ (autonomic) growth of the volume of global demand, we will have to do when reduction of net tax revenue becomes the instrument of fiscal policy and also when an expansive fiscal policy is implemented on the basis of the concept of a balanced budget, i.e. when the growth of state expenditures on the purchase of products is fully financed with the growth of net tax revenue (and will thus not be accompanied by the growth of budget deficit). In the first case, the effectiveness of the fiscal policy will be limited due to the fact that part of the growth of the disposable revenues of production factors (growth obtained by the reduction of net tax revenues) will be used to increase current domestic savings (in consistence with the marginal propensity to save), In the second case, the autonomic growth of the volume of global demand connected with the growth of state expenditures will be largely neutralized by the decline of consumer spending by households (as

${ }^{1}$ Primary (autonomic) growth of the volume of global demand is the growth which will immediately follow the implementation of an expansive fiscal Policy. Primary growth will generate (through multiplying effects in the economy) a whole range of secondary (induced, i.e. growth of output and revenues of production factors related) increases in the volume of global demand which will include increases in consumer spending by households. 
their disposable income decreases in result of an increase of net tax revenues). The scale of neutralization may be even higher because the growth of the tax burden can result in a decline of investment expenditures by enterprises. This variant of fiscal expansion is thus the least effective. Fiscal policy will also be less effective when it takes the form of increase in transfer payments. It is so since increase in transfer payments means in fact increase in the disposable income of households and will not fully translate into primary growth of the volume of global demand.

Thus, what follows from the above analysis is that fiscal expansion is most effective in affecting the volume of global demand in its variants which imply the highest growth of the budget deficit and public debt. The application of an expansive fiscal policy on the basis of the concept of a balanced budget is on the other hand of little sense due to its very low effectiveness.

\subsection{High public debt and high budget economic deficit of the state as barriers to the application of an expansive fiscal policy}

Fiscal expansion based on the growth of budget deficit (as this is, as it has already been said, most effective from the point of view of affecting the volume of global demand) gives rise to a risk of a substantial growth of public debt in relation to GDP. The growth of budget deficit means growth of public debt. This is of particular importance when the level of public debt as a percentage of GDP is already high (Alesina \& Giavazzi, 2013, p. 19). Its further growth (even slight) can mean that the state will become insolvent, i.e. will not be able to repay its debt on time (Botta, 2013, p. 164). In conditions of a high public debt investors can be reluctant to purchase state securities which will make it impossible for the state to roll over the state debt on the required scale. Announcement of insolvency can lead to mass outflow from the economy of convertible currencies (foreign investors will tend to quickly get rid of the securities of the country concerned to minimize the sustained losses) which will result in a sharp depreciation of the currency of the country, a sharp growth of inflation and interest rates. This will in turn mean entering a long period of decline in investment expenditures and real output. The high public debt as a percentage of GDP is thus in practice a barrier to the application of fiscal expansion. In conditions of a high public debt, the budget policy should rather be aimed at generating a budget surplus or at least budgetary balance.

Inability to apply an expansive budgetary policy can also result in a situation when public debt is relatively low but the level of economic deficit of the state is high. The growth of the budget deficit of the state will signify very fast approach to a dangerous (i.e. insolvency-threatening) level of public debt.

Tables 3 and 4 shows the level of public debt for the euro zone countries as a percentage of GDP at the end of 2014 as well as the level of the budget deficit of the state as a percentage of GDP in 2014. 
Of the twelve countries which recorded the lowest economic growth rate over the past five years as many as nine belong to the first ten of the euro zone countries with the highest level of public debt as a percentage of GDP and simultaneously to the group of ten countries with the highest budget deficit in relation of GDP. Thus, these nine countries are characterized not only by a very high public debt but also very high growth of the debt over the year. These countries are: Belgium, Ireland, Greece, Spain, France, Italy, Cyprus, Portugal and Slovenia. In eight of these countries (apart from Slovenia) public debt exceeds $100.0 \%$ of GDP or approaches $100.0 \%$ of GDP. In Slovenia, public debt exceeded $80.0 \%$ of GDP. In six of the nine countries with the worst state of public finances the budget deficit is higher than $4.0 \%$ of GDP and in three subsequent ones it exceeds $3.0 \%$ of GDP. Consequently, these nine countries bear the highest risk of insolvency. In fact some of them have already experienced the phase of being unable to timely repay their debt (Greece, Cyprus) and their economies are already affected by the negative consequences of this phenomenon. In these nine countries there is thus no longer a possibility to pursue an expansive fiscal policy, that is to attempt to stimulate economic growth through further increase of the budget deficit. Neither does Austria have such an option in practice. Though it has a relatively low level of the state budget deficit in relation to GDP (below $2.5 \%$ of GDP), its public debt amounts to nearly $85.0 \%$ of GDP.

Among the twelve euro zone countries with the lowest economic growth rate solely the Netherlands and Finland have yet room for an expansive budget policy. In the Netherlands the level of public debt is relatively low ( below $70.0 \%$ of GDP) and the level of the state budget deficit is also low. On the other hand, in Finland the budget deficit exceeds $3.0 \%$ of GDP while public debt is below $60.0 \%$ of GDP.

The countries which registered the highest average annual economic growth rate in the euro zone in the years 2010-2014 (from 1.8\% to 3.7\%) and in which short-term stimulation of this growth through fiscal expansion is not necessary enjoy simultaneously a good condition of public finances. Paradoxically, it is in these countries that there is room for an expansive budgetary policy. Germany, the largest economy of the euro zone, is the leading country of this group. Since 2012 the budget of the German state (understood as the sector of public finances as a whole) has been showing a surplus. In 2014, the latter amounted to $0.7 \%$ of GDP. And this is what allowed Germany to embark on the path of the reduction of the public debt in relation to GDP. Unfortunately, the remaining countries of the group with the highest economic growth rate and good condition of public finances are economies of almost negligent share in the economy of the euro zone. They are: Estonia, Lithuania, Latvia, Slovakia, Malta, Luxemburg. 


\subsection{Barriers to the transmission of an expansive fiscal policy to the growth of the real volume of global demand and growth of the real volume of domestic production}

As it has been mentioned earlier, an expansive fiscal policy can affect the real volume of domestic production by increasing the volume of global demand. The ineffectiveness of the policy of budget deficit growth in shaping the real GDP can have its source in the fact that fiscal expansion will not translate into growth in the volume of global demand. Supply-side economists emphasize that growth of the volume of demand on the part of the state can be neutralized by reducing the volume of demand on the part of the private sector. It is so because increase of the state budget deficit can lead to a decline in consumer spending by households and decline in investment expenditures by enterprises (Ricardo equivalence theorem) (Krawczyk, 2013, p. 43). Fiscal expansion, particularly in conditions of a high public debt in relation to GDP, will, according to supply-side economics, generate on the part of households and enterprises expectations of an increase in the tax burden in the future.

The budget deficit and public debt growth-related expectations of growth in the tax burdens on the part of the private sector have their source in (Rosati, 2013, p. 27):

- higher costs of debt service because the scale of the debt increases and consequently also the profitability of government bonds (the profitability increases due to bigger demand for savings on the part of the state and a higher premium for the risk the state must offer to investors);

- the state will have to begin to generate budget surpluses to enter the path of public debt reduction and this will entail, among others, the necessity to raise taxes.

An expansive fiscal policy can contribute to a decline in investment expenditures by enterprises also through an increase in the market interest rate and the crowding-out effect (Easterly \& Rebelo, 1993, p. 62). It is so because growth of the budget deficit leads to growth of demand for savings in the economy (if it is financed with domestic savings) which in turn results in growth of the market interest rate (and thus the price of raising savings which are a source of investment financing goes up). In effect, fewer domestic savings find their way to enterprises which translates into a downward trend in investment expenditure. Another mechanism underpinning the growth of interest on credit can be the increase on the part of banks of the perception of an increased corporate credit-related risk in connection with increased tax burdens. A higher-than-average interest rate also means more expensive credit for households which will in turn have an adverse impact on the level on consumer spending.

Referring these considerations to the current situation in the euro zone it seems likely that fiscal expansion might contribute to growth of the volume of global demand as it would not encounter the majority of the barriers referred to above. Fiscal expansion would be very unlikely to have any significant impact 
on the level of investment expenditures, nor on the level of consumer expenditure through the growth of savings on the part of the state. The level of market interest rates in the euro zone is at present very low due the deflationary processes taking place in the euro zone economy. The current aim of the European Central Bank is make the euro zone economy recover from deflation which makes them tend to favour an expansive monetary policy. Monetary expansion pulls market interest rates down and would neutralize the effects of the influence of the growth of the budget deficit on these rates. Moreover, the growth of the budgetary deficit can be financed from foreign savings and then fiscal expansion will not influence the price of savings in a given economy. It can also be assumed that the growth of budget deficit and public debt would not shape the expectations of private sector entities towards growth of tax burdens. It should be kept in mind that in spite of the high public debt the profitability of government bonds in the euro zone still remains very low. This is a consequence of very low interest rates of the central bank as well as market interest rates and the fact that the majority of euro zone countries need not offer investors a high risk-related premium. As a whole, the euro zone is still perceived as a safe area for investment in debt treasury securities (Pronobis, 2014). Expectations of tax burden growth can however have their source in the fact that the majority of the euro zone countries will soon have to embark on the path of reducing their public debt. The level of the tax burden in the euro zone countries is however already so high (the highest in the world) and already has an adverse influence on the efficiency of their economies. In 2014, the mean rate of fiscal stringency in the euro zone countries amounted to $46.6 \%$ and in a few of them even exceeded 50.0\% (France, Belgium, Finland) (Eurostat, 2015). Therefore the choice of a further increase in tax rates as a way of reducing public debt would be detrimental. The factor which might reduce the effectiveness of the impact of the growth of the budget deficit on the growth of global demand may turn out to be the already referred to deflation (Rzońca, 2014, p. 121). Deflation tends to lead to decrease in the volume of demand on the part of the private sector (both households and enterprises withhold spending, the so called second-round effect). Deflation is accompanied by phenomena such as decrease in wages by enterprises (in particular, when deflation has its source in economic recession, as the case is in the euro zone), decline in the readiness to draw credit on the part of households and enterprises, expectation of even lower prices and even lower interest rates. All this can lead to a situation when the effects of the impact of fiscal expansion on the growth of the volume of global demand will be partly reduced by decline in consumer and investment expenditures.

In the euro zone, fiscal expansion can encounter barriers to effective impact on the level of real output also at the stage of the reaction of enterprises to the growth of the volume of global demand. It may turn out that enterprises may be reluctant to reach for non-used resources of production factors (underutilization of production factors, both labour and fixed capital in the euro zone economy are now grossly underutilized) and to respond to the growth of the vol- 
ume of global demand with growth of real output. This results from the presence in the euro zone economy of a number of factors which make the conditions of production unfavourable (as they lower the competitiveness of production). This refers, among others, to the already mentioned high tax burden, high labour costs and inflexibility of the labour market as well as the high level of red tape. It might be worthwhile to mention here that in spite of a very expansive fiscal policy which we have witnessed in the economy of the euro zone in the years 2008-2009 (the economic deficit of the state budget increased in this period from $0.7 \%$ of GDP to $6.4 \%$ of GDP) in the years 2010-2011 (transmission of the fiscal policy to real economy comes with a delay) the economic growth rate was very low (in spite of the fact that the base for this period was the year 2009, in which deep recession was registered) (Eurostat, 2015).

\subsection{Effectiveness of fiscal expansion under different exchange rate systems}

The effectiveness of fiscal expansion in its impact on the level of real output is determined also by the exchange rate system applied in a given country (Lenza et al., 2010, pp. pp. 295 to 339). Let us consider the effects of budget deficit growth under the floating exchange rate system and under the fixed exchange rate system. The analysis will be carried out on the assumption of high mobility of portfolio capital between economies. The assumption reflects the realities of the today's global economy. We also assume that fiscal expansion has contributed to growth of global demand as well as that enterprises are ready to respond to the growth of demand with quantitative adjustments.

Under a floating exchange rate system, the exchange rate depends solely on the relationship between demand and supply on the foreign exchange market in the economy. In this system the central bank which is responsible for the exchange rate policy does not need (though can) intervene in the foreign exchange market.

Under a fixed exchange rate system the central bank sets the so called benchmark rate and the admissible band of fluctuations from the benchmark rate (the so called spread) within which the exchange rate can fluctuate on the foreign exchange market. When the exchange rate on the foreign exchange market exceeds the set band of fluctuations, the central bank is obliged to intervene.

With the adopted assumptions, an expansive fiscal policy will lead, in the first place, to the growth of real output and growth of the mean market interest rate. The growth of the interest rate can be explained, among others, in terms of changes which will take place on the money market. The growth of real output will cause the growth of demand for money and consequently increase of the price of money. Assuming the high portfolio capital mobility, the growth of the interest rate will result in an emergence of a balance of payments surplus (in spite of the growth of import expenditures resulting from the growth of the volume of production and in consequence revenues of pro- 
duction factors). The surplus in the balance of payments will generate pressure towards appreciation of the domestic currency. Under a floating exchange rate system in force, this appreciation will follow. The appreciation will in turn lead to a decline in the volume of global demand (as export will decrease and import increase) and in consequence a decline in real output. The growth of production generated by the growth of the budget deficit will thus be partly or entirely neutralized by the decline in production related to the appreciation of the domestic currency.

The system of a floating exchange rate thus constitutes a barrier to an effective impact of an expansive fiscal policy on the level of real output.

When the system of a fixed exchange rate is in force (assuming a narrow admissible band of exchange rate fluctuations), the central bank will be forced to limit the scale of the appreciation through intervention in the form of purchase of foreign currencies on the foreign exchange market (with the domestic currency). In effect the quantity of money in the economy will increase. Thus, in this case, fiscal expansion will impose an expansive monetary policy. Monetary expansion will generate further growth of the volume of global demand and further growth of real output. Consequently, the fixed exchange rate system increases the effectiveness of the growth of budget deficit in its impact on the growth of production. It makes the effectiveness of fiscal expansion even higher than it would be in conditions of a closed economy (that is in the absence of trade in products and savings with abroad).

In the euro zone, the system of a floating exchange rate is applied in relation to the currencies of non-EU countries. On the other hand, in relation to the currencies of EU countries being outside the euro zone, the system of a fixed exchange rate is applied. The market exchange rate can fluctuate by as much as $+/-15 \%$ from the set benchmark rate which in practice means a floating rate also against these currencies. As it has been shown above, the floating exchange rate system has an adverse influence on the effectiveness of an expansive fiscal policy in its impact on the level of real output. Under this exchange rate regime the growth of the budget deficit results in the appreciation of the domestic currency. It should be emphasized that for the euro zone the importance of the barrier of the effectiveness of fiscal expansion in the form of the floating exchange rate system would be much greater if not for the fact that it is other euro zone countries that account for the prevailing majority of the foreign trade exchange of euro zone countries. Consequently, the appreciation of the euro affects solely the level of net export to non-euro zone countries.

\subsection{The effectiveness of expansive fiscal policy under different variants of monetary policy}

The effects of the impact of the growth of budget deficit on the economy are also influenced by the variant of the central bank monetary policy which accompanies fiscal expansion (Stiglitz, 2012, p. 19). Let us consider the impact on fiscal 
expansion of a restrictive and expansive monetary policy under the floating exchange rate system. Under the fixed exchange rate system the monetary policy does not influence the effects of fiscal expansion. In conditions of a fixed exchange rate the effects of the impact of the monetary policy on production are fully neutralized by the effects of the necessary central bank interventions on the foreign exchange market on the level of production. In addition, as it has already been said, in practice, the system of a floating exchange rate applies to all currencies in the euro zone.

Let us now have a look at a situation when the growth of the budget deficit is accompanied by an expansive monetary policy, that is growth of money supply in the economy. An expansive monetary policy in itself contributes (in the presence of the adopted assumptions) to an increase in real output and decrease in the average market interest rate (Kozłowski, 2010, p. 8). When fiscal expansion is accompanied by monetary expansion the growth of production is thus bigger than in the case of fiscal expansion only. It is the scale of the latter that determines how much the budget policy can be strengthened by an expansive fiscal policy. With strong monetary expansion, despite a simultaneous fiscal expansion, the market exchange rate declines and a deficit appears in the balance of payments. Under the system of a floating exchange rate, the deficit in the balance of payments results in depreciation of the local currency. The depreciation, in turn, becomes another source of the growth of the volume of global demand as it leads to an increase in export and decrease in import. When the growth of the budget deficit is accompanied by an expansive monetary policy, the effects of fiscal expansion in its impact on the growth of production are greater (in comparison with fiscal expansion alone) because monetary expansion restrains (when its scale is weak) or completely eliminates (when its scale is strong) barriers to the effectiveness of fiscal expansion in the form of growth of the market interest rate (monetary expansion limits or eliminates the crowding-out effect linked to fiscal expansion) and appreciation of the domestic currency. When monetary expansion is strong, then despite an expansive fiscal policy the volume of demand on the part of the private sector increases. Not only is the crowding-out effect related to the budget deficit growth being completely eliminated but the volume of global demand increases faster than the volume of demand on the part of the state. Moreover, when monetary expansion is strong, then, despite fiscal expansion, the domestic currency does not appreciate but depreciates. Consequently, the effects of fiscal expansion are not limited by net export decrease but are additionally strengthened by net export increase.

Under the system of a floating exchange rate the influence of the budget deficit growth on the level of real output can be limited through a restrictive monetary policy (that is decrease in the volume of money supply) (Peersman, 2011, p. 88). The central bank responds to fiscal expansion with a restrictive monetary policy fearing that the growth of budgetary deficit can cause too high a rise of the inflation rate. When fiscal expansion is accompanied by a restrictive monetary policy, the growth of the interest rate is higher than in the case 
of fiscal expansion alone. This generates a higher balance of payments surplus, a higher appreciation of the domestic currency and a higher decrease in net export. A higher increase in the market interest rate causes also a higher decrease in the volume of demand on the part of the private sector (a larger scale of the crowding-out effect). All this makes the growth of real output smaller. Under a strong restrictive monetary policy fiscal expansion will be entirely ineffective in its impact on the level of production.

The monetary policy currently pursued in the euro zone can favour the effectiveness of the impact of an expansive fiscal policy on the level of production. As it has already been mentioned in connection with deflation in the euro zone, the European Central Bank pursues an expansive monetary policy. Fiscal expansion would not change their attitude as there are no grounds to fear that it would contribute to an excessive rise in the inflation rate. As for the ECB, it has already exhausted possibilities of implementing monetary expansion with the help of monetary policy conventional instruments, that is central bank interest rates (as ECB interest rates are already near zero). Since March 2015 the ECB has been applying one of the instruments of unconventional monetary policy, namely quantitative easing $(\mathrm{QE})^{2}$. Quantitative easing consists in the purchase by the central bank of different securities from commercial banks or other entities (for instance, the state) (Żywiecka, 2013). Thus, quantitative easing involves unconditional open market operations. The aim of quantitative easing by the ECB is to help the euro zone economy to recover from deflation. After successful recovery from inflation, quantitative easing will become an additional factor of the influence of monetary policy on the effectiveness of an expansive fiscal policy since, as it has been said above, deflation constitutes an essential barrier to the transmission of fiscal expansion to growth of global demand and growth of the volume of production. It should however be emphasized that an expansive monetary policy can also encounter barriers. This is also true of the present macroeconomic situation of the euro zone.

\section{Conclusion}

1. In the majority of the euro zone countries which have reported a very low economic growth rate over the past years, it is practically impossible to apply an expansive fiscal policy due to a high level of public debt in relation to GDP and a high level of budget deficit in relation to GDP.

2. In the euro zone, expectations of economic entities regarding the growth of the tax burden do not constitute barriers to the transmission of budget deficit growth to the growth of the volume of global demand.

3. In the euro zone, the growth of the volume of global demand resulting from an expansive fiscal policy may not translate, in a significant way, into growth of real output due to the reluctance of enterprises to increase the utilization

\footnotetext{
${ }^{2}$ ECB announces expanded asset purchase programme (EBC, 2015).
} 
of production factors given the poor production conditions (among others, high tax burden, high labour cost).

4. Another factor of negative influence on the effects of the impact of fiscal expansion on the level of real output in the euro zone is the floating exchange rate system applied to practically all currencies.

5. The expansive monetary policy being pursued by the ECB will continue to strengthen the effects of the impact of the budget deficit growth on the level of real output by eliminating such barriers as the growth of the mean market interest rate or the appreciation of the domestic currency.

\section{References}

Alesina, A., \& Giavazzi, F. (2013). Fiscal Policy after the Financial Crisis. Chicago: University of Chicago Press.

Botta, A. (2013). Fiscal policy, Eurobonds, and economic recovery: heterodox policy recipes against financial instability and sovereign debt crisis. Journal of Post Keynesian Economics, 35(3). doi:10.2753/pke0160-3477350305.

Bureau of Economic Analysis. (2015). Retrieved 30.12.2015 from https://www. bea.gov.

Domańska E. (1992). Wokót interwencji państwa w gospodarkę, Keynes, Friedman, Laffer, Reagan i inni. Warszawa: PWN.

Easterly W., \& Rebelo S. (1993). Fiscal policy and economic growth. Journal of Monetary Economics, 32(3). doi:10.1016/0304-3932(93)90025-B.

ECB. (2015). Retrieved 30.12.2015 from www.ecb.europa.eu.

Eurostat. (2010). ESA Manual on Government Deficit and Debt. Retrieved 30.12.2015 from http://ec.europa.eu/eurostat.

Eurostat. (2015). Retrieved 30.12.2015 from http://ec.europa.eu/eurostat.

Kozłowski, T. (2010). Akcelerator finansowy jako koncepcja mechanizmu amplifikacji zewnętrznych zakłóceń gospodarczych. Ekonomia i Prawo, 6(1). doi:10.12775/eip.2010.011.

Krawczyk, M. (2013). Putapka ptynności a monetarna akomodacja fiskalnej ekspansji. Warszawa: SGH.

Lenza, M., Pill, H., \& Reichlin, L. (2010). Monetary policy in exceptional times. Economic Policy, 25(62). doi:10.1111/j.1468-0327.2010.00240.x.

Peersman, G. (2011). Macroeconomic effects of unconventional monetary policy in the euro area. EBC Working Papers Series, 1397.

Pronobis, M. (2014). Rola polityki Europejskiego Banku Centralnego w zarządzaniu antykryzysowym w Europie, Zeszyty Natolińskie, 58.

Rosati, D. (2013). Konsolidacja fiskalna a kryzys zadłużenia w strefie euro. In L. Oręziak, \& D. Rosati (Eds.), Kryzys finansów publicznych - przyczyny, mechanizm, droga wyjścia. Warszawa: Uczelnia Łazarskiego.

Rzońca, A. (2014). Kryzys banków centralnych. Skutki niskich stóp procentowych. Warszawa: C.H. Beck. 
Stiglitz, J. (2012). Macroeconomics, Monetary Policy and the Crisis. In O. Blanchard, D. Romer, M. Spence, J. Stiglitz J. (Eds.), In the wake of the crisis: leading economists reassess economic policy. Cambridge: MTI Press.

Wernik, A. (2011). Problemy definicji długu publicznego. Studia BAS, 4(28). World Bank. (2015). Retrieved 30.12.2015 from http://data.worldbank.org. Żywiecka, H. (2013). Niestandardowe dziatania banków centralnych $w$ warunkach globalnego kryzysu finansowego, Warszawa: CeDeWu.

\section{Acknowledgements}

Author contributions: author have given approval to the final version of the article. 


\section{Appendix}

Table 1.

Rate of change of real GDP in euro zone countries in the years 2010-2014 (in \%)

\begin{tabular}{crrrrrr}
\hline Country & 2010 & 2011 & 2012 & 2013 & 2014 & \multicolumn{2}{l}{ Average } \\
\hline Belgium & 2.3 & 1.9 & -0.1 & 0.2 & 1.1 & 1.1 \\
Germany & 3.7 & 3.0 & 0.7 & 0.4 & 1.6 & 1.9 \\
Estonia & 2.3 & 7.6 & 4.5 & 2.2 & 2.1 & 3.7 \\
Ireland & -1.1 & 2.2 & 0.2 & -0.3 & 4.8 & 1.2 \\
Greece & -4.5 & -6.9 & -7.0 & -3.9 & 0.8 & -4.3 \\
Spain & -0.1 & 0.7 & -1.6 & -1.2 & 1.4 & -0.2 \\
France & 1.5 & 1.7 & 0.0 & 0.2 & 0.2 & 0.7 \\
Italy & 1.3 & 0.4 & -2.4 & -1.9 & -0.4 & -0.6 \\
Cyprus & 1.0 & 0.5 & -2.4 & -5.4 & -2.3 & -1.7 \\
Latvia & -0.3 & 5.5 & 5.2 & 4.1 & 2.4 & 3.4 \\
Lithuania & 1.3 & 5.9 & 3.7 & 3.3 & 2.9 & 3.4 \\
Luxemburg & 3.5 & 1.6 & -0.2 & 2.1 & 2.1 & 1.8 \\
Malta & 2.7 & 2.1 & 1.1 & 2.9 & 3.5 & 2.5 \\
Netherlands & 1.7 & 1.2 & -1.2 & -0.8 & 0.9 & 0.4 \\
Austria & 2.3 & 3.1 & 0.9 & 0.3 & 0.3 & 1.4 \\
Portugal & 1.3 & -1.6 & -3.2 & -1.4 & 0.9 & -0.8 \\
Slovenia & 2.0 & -0.2 & -2.5 & -1.1 & 2.6 & 0.2 \\
Slovakia & 4.4 & 3.3 & 1.8 & 0.9 & 2.4 & 2.6 \\
Finland & 3.6 & 2.9 & -1.0 & -1.4 & -0.1 & 0.8 \\
\hline
\end{tabular}

Source: Own elaboration on the basis of Eurostat (2015). 
Table 2.

Average annual rate of real GDP change in selected non-European countries in the years 2009-2013 (in \%)

\begin{tabular}{cr}
\hline Country & GDP growth rate \\
\hline Canada & 1.38 \\
Mexico & 1.90 \\
Brazil & 2.68 \\
Argentina & 4.34 \\
RSA & 1.92 \\
Egypt & 3.18 \\
China & 8.86 \\
Japan & 0.32 \\
South Korea & 3.09 \\
Saudi Arabia & 5.48 \\
Turkey & 3.86 \\
Malaysia & 4.26 \\
Indonesia & 5.88 \\
Thailand & 3.02 \\
Iran & 2.0 \\
Australia & 2.44 \\
\hline
\end{tabular}

Source: Own elaboration on the basis of World Bank (2015).

Table 3.

Public debt in relation to GDP at market prices in euro zone countries at the end of 2013 (according to ESA 2010 methodology) (in GDP \%)

\begin{tabular}{cr}
\hline Country & Public debt \\
\hline Belgium & 106.5 \\
Germany & 74.7 \\
Estonia & 10.6 \\
Ireland & 109.7 \\
Greece & 177.1 \\
Spain & 97.7 \\
France & 95.0 \\
Italy & 132.1 \\
Cyprus & 107.5 \\
Latvia & 40.0 \\
Lithuania & 40.9 \\
Luxemburg & 23.6 \\
Malta & 68.0 \\
Netherlands & 68.8 \\
Austria & 84.5 \\
Portugal & 130.2 \\
Slovenia & 80.9 \\
Slovakia & 53.6 \\
Finland & 59.3 \\
\hline
\end{tabular}

Source: Own elaboration on the basis of Eurostat (2015). 
Table 4.

State budget result in relation to GDP at market prices in euro zone countries in 2014 (according to ESA 2010 methodology) (in GDP \%)

\begin{tabular}{cr}
\hline Country & State budget result \\
\hline Belgium & -3.2 \\
Germany & 0.7 \\
Estonia & 0.6 \\
Ireland & -4.1 \\
Greece & -3.5 \\
Spain & -5.8 \\
France & -4.0 \\
Italy & -3.1 \\
Cyprus & -8.8 \\
Latvia & -1.4 \\
Lithuania & -0.7 \\
Luxemburg & 0.6 \\
Malta & -2.1 \\
The & -2.3 \\
Austria & -2.4 \\
Portugal & -4.5 \\
Slovenia & -4.9 \\
Slovakia & -2.9 \\
Finland & -3.2 \\
\hline &
\end{tabular}

Source: Own elaboration on the basis of Eurostat (2015). 
